\title{
IMPROVING STUDENTS' SPEAKING SKILL USING RADIO TALK SHOW PROGRAMME
}

\author{
Dewi Satria Elmiana \\ Universitas Mataram \\ elmianadewi@gmail.com
}

\begin{abstract}
Media provide students and teachers with creative as well as practical ideas and enable them to meet various interests and needs. Hence, this study analysed the implementation of using media particularly radio programme to improve students' speaking skill. This study employed action research and there were 42 students of senior high school involved in this study. The results indicate that the implementation of media (radio talk show programme) assists students to improve their speaking skill. It can be one of methods in teaching and learning process especially in speaking class; and the influence of media (radio talk show programme) could encourages and motivates students to pull out their best of communication skill particularly in using English.
\end{abstract}

Keywords: Radio programme, talk show, speaking English, teaching and learning.

\section{A. INTRODUCTION}

peaking is one of skills in learning a language and enables people to send and receive information or messages to others. 'Speaking is utterances or speech with the purpose of having intention to be recognized by speaker and receiver processes the statements in order to recognize their intentions' (Gert and Hans, 2008, p. 207 in Efrizal, 2012). Moreover, according to Surkamp (2012), speaking is a process of building and sharing meaning using verbal and non-verbal symbol in various contexts and in some situations may be totally non interactive such as when recording a speech for radio broadcast. Media provide students and teachers with creative as well as practical ideas and enable them to meet various interests and needs. Media not only entertain students, but also giving them confidence and motivation to practice their English skill outside of classroom activities (Biagy, 1996). One of media that people interact with is radio. Radio has capability capability to encourage people listening to it. 'Radio plays an important part in developing people's imagination, in creating pictures in the mind through the power of words, it stimulates the imagination to fill in the visuals, thus, it helps students to promote their imagination and to voice their creativity' (Tafani, 2009, p. 86). There are many services offered by radio station to satisfy the listeners. One of the most favourite programmes is an interactive phone line between broadcasters and listeners. Therefore, this study analyses the implementation of using media, particularly radio programme, to improve students' speaking ability. 


\section{Volume 5, Number 02, December 2019}

\section{B. REVIEW OF LITERATURE}

\section{Communicative approach}

Nowadays, the effect of Communicative Language Teaching (CLT) approach has spread extensively into the process of teaching and learning (Celce Muria, 2001). CLT is primarily concerned on what will students will and views of a language as a means of communication (Hubbard, 1995). According to Elmiana (2018, p. 463) 'the key theoretical point of CLT is communicative competence'. Hence, CLT aids students to successfully communicate in target language (Celce Muria, 2001; Nunan, 2004). However, in teaching and learning process, the role of teachers should be to acquaint with the functions and structures of communicative activities in a ' controlled manner', thus, students might be able to respond to the appropriate meaning (Klapper, 2003). The use of CLT approach assists students to successfully communicate in target language (Celce - Muria, 2001; Nunan, 2004). According to Bygate (1987) to achieve communicative goal through speaking, there are two aspects to be considered, knowledge of the language, and skill in using this knowledge. It is not enough to possess a certain amount of knowledge, but a speaker of the language should be able to use this knowledge in different situations. We do not merely know how to assemble sentences in the abstract, we have to produce them and adapt to the circumstances. This means making decision rapidly, implementing them smoothly, and adjusting our conversation as unexpected problems appear in our path (Bygate, 1987). Being able to decide what to say on the spot, saying it clearly and being flexible during conversations different situations come out is the ability to use the knowledge 'in action', which creates the second aspect of speaking. To improve students' communicative skill, the help of media particularly radio would be worth to discuss.

\section{Radio broadcasting communication}

Radio broadcasting communication is when somebody talks on radio as communicator that convey information, ideas, and feeling to listener through the radio. A person who does not have any trouble in speaking (mute, nasal, or lips) basically is able to speak normally to other people on the radio as an announcer, reporter, actress/ actor or guest speaker, but it needs a particular requirement in getting a good voice that can be listened by the listener clearly (Evita, 2009). According to Person and Banet in Sudharita (2005) stated that radio is not only to find the similarities of understanding from the information but also in order to secure understanding, establish acceptance, and motivate action. Thus, it must be ascertained that listeners understand or comprehend the message that is conveyed by the broadcaster. When the listener understood the message and accept it, the acceptance is established (Harry, 2010). Subsequently, the announcer presents the next action to motivate the listeners to do a certain activity according 
Dewi Satria Elmiana, Improving Students' Speaking...

to the planning that had made by the announcers. Nevertheless, there might be some obstacles happened that cannot construct the process of effective communication which have to be solved in a right way. As communication process through radio is considered as communication where the information is only absorbed by human's hearing (Bethesda, 2007). Hence, it might needs a deep analysis in order to achieve an effective communication. There are several essential principles in radio communication which are (a) using communicative language; (b) radio is a media of communication; (c) communication that is done through the radio is the communication between persons; (d) there is only a chance to listen for the listener; and (e) communication on the radio exploits voices that only conveying the message. Communication on radio relies on a conversation, thereby, communication should deliver in a common way and using common words (Sudharita, 2005). If the speakers used numeral sign, it should be to the point of the problem, except in a particular thing such as in an athletic competition.

\section{Study on the use of radio programme as a medium for speaking}

Radio programme as a medium for speaking is one of the way media influences speaking skill that radio is commonly known as programme that use phone line to interact with the audience in the form of conversation. There are few studies on using radio as a media of improving students' speaking skill. One of studies has been conducted by Wahyudi (2004) entitled 'miscommunication in radio communication broadcast between announcer and caller'. The objective of study was analysing interaction between announcer and caller regarding topics, announcer quality, material quality, and other interesting components that can be revealed in their interaction during conversation. The method used was descriptive qualitative and data were from written communication between announcer and caller or listener in radio conversation by employing participatory observation. From the data analysis, it was found that in radio conversation there were internal and external factors that influence the effectiveness of communication, also found that the communication strategy to overcome the communication problems in the radio conversation broadcast between announcer and listener/ caller. For the study above, radio is one of media that able to measure speaking skill and identify problems in speaking especially in communication between announcer and caller. This study uses similar media to analyse students' speaking skill by radio talk show programme, however, the difference is in the objective of study which the current study attempts to identify the influence of talk show programme as a medium to improve students' speaking skill. 


\section{Volume 5, Number 02, December 2019}

\section{METHOD}

This study employed action research. This study analysed how media being used to improve students' speaking skill when they were as guest star in talk show radio programme. Whilst being a guest star, they will be asked to perform their understanding in the latest issues or topics. There were 42 students of senior high school involved in this study. The data collection is divided into three phases:

1. On the first phase (4 weeks) students asked to choose 1 out of 3 topics, the topics were how to be good student, the criteria of good teacher, and how to pass an examination. There were maximum 12 students participated in four consecutive weeks as guest star. This phase focused on students' speaking skill which are accent, grammar, vocabulary, fluency, and comprehension.

2. On the second phase (4 weeks) students discussed only one topic. The topic was what is your most interesting experience in life. The rules for this session were similar with the first one, students in turns being guest stars. This phase also focused on the students' speaking skill such as accent, grammar, vocabulary, fluency, and comprehension.

3. On the third phase (4 weeks), they discussed about hobbies with trying to perform long conversation. This session focused on accent, grammar, vocabulary, fluency and comprehension.

\section{Population and sample}

The population of students were 286 students and the sample were 42 students. This study used purposive sampling technique due to the qualities of informant possesses and the researcher decided what needs to be known and sets out to find participant who is willing to provide information by experience or knowledge (Bernard, 2002; Lewis and Sheppard, 2006). The radio where one of programme was held in one of well know radio namely Happy Line Service. The reason of choosing this programme was it uses English as the language for communication to discuss current issues and debates.

\section{Method of data collection}

In collecting the data, a tape recorder was used to record of the all conversation among students, broadcasters and callers. All of the conversation were transcribed. In analysing the development of students' speaking skill, this study followed the scoring criteria proposed by Heaton (1991) below: 
Dewi Satria Elmiana, Improving Students' Speaking...

Table 1. Scoring Criteria

\begin{tabular}{|c|c|}
\hline \multicolumn{2}{|r|}{ Accent } \\
\hline 1 & Pronunciation frequently unintelligible \\
\hline 2 & $\begin{array}{l}\text { Frequent gross errors and a very heavy accent make understanding } \\
\text { difficult, require frequent repetition }\end{array}$ \\
\hline 3 & $\begin{array}{l}\text { Foreign accent requires concentrated listening and mispronunciation lead } \\
\text { to occasional misunderstanding and apparent errors in grammar and } \\
\text { vocabulary }\end{array}$ \\
\hline 4 & $\begin{array}{l}\text { Marked foreign accent and occasional mispronunciation which do not } \\
\text { interfere with understanding }\end{array}$ \\
\hline 5 & $\begin{array}{l}\text { No conspicuous mispronunciation, but would not be taken for a naïve } \\
\text { speaker }\end{array}$ \\
\hline 6 & Native pronunciation with no trace of foreign accent \\
\hline \multicolumn{2}{|r|}{ Grammar } \\
\hline 1 & Grammar almost entirely inaccurate phases \\
\hline 2 & $\begin{array}{l}\text { Constant errors showing control of very few major patterns and frequently } \\
\text { preventing communication }\end{array}$ \\
\hline 3 & $\begin{array}{l}\text { Frequent errors showing some major patterns noncontrolled and causing } \\
\text { occasional irritation and misunderstanding }\end{array}$ \\
\hline 4 & $\begin{array}{l}\text { Occasional errors showing imperfect control of some patterns but no } \\
\text { weakness that causes misunderstanding }\end{array}$ \\
\hline 5 & Few errors with no patterns of failure \\
\hline 6 & No more than two errors during the interview \\
\hline \multicolumn{2}{|r|}{ Vocabulary } \\
\hline 1 & Vocabulary inadequate for even the simplest conversation \\
\hline 2 & $\begin{array}{l}\text { Vocabulary limited to basic personal and survival areas ( time, food, } \\
\text { transportation, family, etc ) }\end{array}$ \\
\hline 3 & $\begin{array}{l}\text { Choice of words sometimes inaccurate, limitation of vocabulary prevent } \\
\text { discussion or some common professional and social topics }\end{array}$ \\
\hline 4 & $\begin{array}{l}\text { Professional vocabulary adequate to discuss special interest; general } \\
\text { vocabulary permits discussion of any non - technical subject with some } \\
\text { circumlocutions }\end{array}$ \\
\hline
\end{tabular}


Volume 5, Number 02, December 2019

\begin{tabular}{ll}
\hline 5 & $\begin{array}{l}\text { Professional vocabulary broad and precise, general vocabulary adequate to } \\
\text { cope with complex practical problems and varied social situations }\end{array}$ \\
\hline 6 & $\begin{array}{l}\text { Vocabulary apparently as accurate and extensive as that of an educated } \\
\text { native speaker }\end{array}$ \\
\hline 1 & Fluency \\
\hline 2 & Speech is so halting and fragmentary that conversations is virtually \\
\hline 3 & Speech is very slow and uneven except for short or routine sentences \\
\hline 4 & Speech is frequently hesitant and jerky; sentences may be left uncompleted \\
\hline 5 & $\begin{array}{l}\text { Speech is occasionally hesitant with some evenness caused by rephrasing } \\
\text { and grouping for words }\end{array}$ \\
\hline 6 & Speech is effortless and smooth but perceptibly non- native in speech and \\
& evenness \\
\hline
\end{tabular}

\section{Comprehension}

\begin{tabular}{ll}
\hline 1 & Understand too little for the simplest type of conversation \\
\hline 2 & Understand only slow, very simple speech no common social and touristic \\
& topics; requires constant repetition and rephrasing \\
\hline 3 & Understand careful, somewhat simplified speech when engaged in a \\
& dialogue, but may require considerable repetition and rephrasing \\
\hline 4 & Understand quite well normal educated speech when engaged in a dialogue, \\
& but requires occasional repetition and rephrasing \\
\hline 5 & Understand everything in normal educated conversation except for very \\
& colloquial or low frequency items, or exceptionally rapid or slurred speech \\
\hline & Understand everything in both formal and colloquial speech to be expected \\
&
\end{tabular}

After the data completed, the next step was transcribing it in a form of conversation text. It took great patience and concentration in doing this especially when dealing with fast - rate speech. After the transcription completed, it would be checked again to avoid the mistake before typing it in form of conversation text. The last step was selecting the data to identify the interaction among broadcaster, students, and callers. 
Dewi Satria Elmiana, Improving Students' Speaking...

\section{FINDINGS AND DISCUSSION}

After finished conducting the three phases or cycles of data collection and completed data analysis, the findings showed that there was a different total amount of mean score from first, second and third phase which can be considered as a media influences students' speaking skill. It can be seen from the graph 1 that there was a mean score in each phase rose significantly. However, in terms of accent, grammar, and vocabulary have a slight difference rather than in fluency and comprehension that inclined significantly.

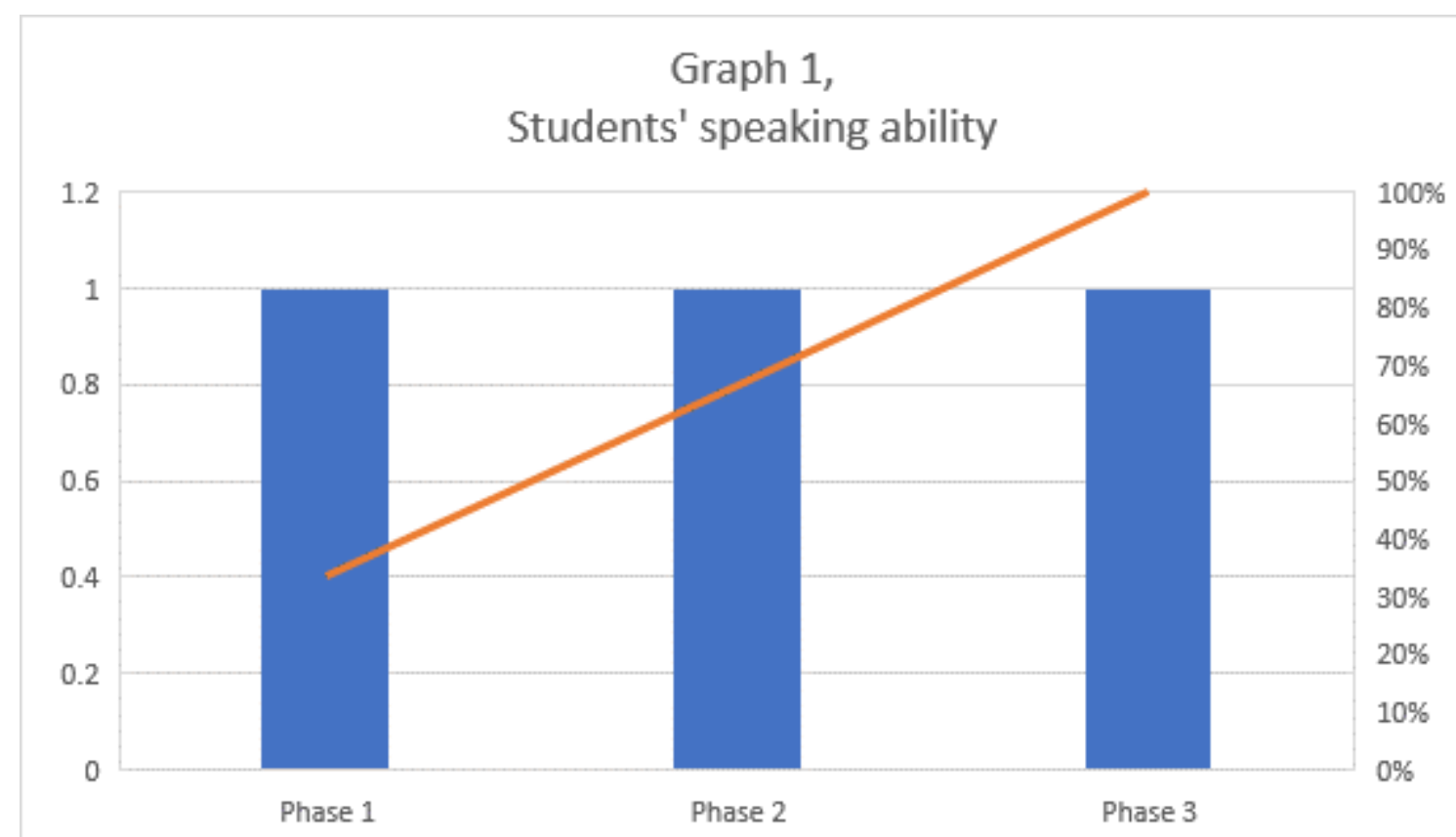

Figure 1. Students' speaking ability

The graph 1 above indicated that (1) students' accent was influenced by mispronunciation lead to occasional misunderstanding and apparent errors in grammar and vocabulary; (2) grammar was influenced by patterns uncontrolled and causing misunderstanding; (3) vocabulary was influenced by limited to basic personal and survival areas related to the topics; (4) fluency, the data found that the differences among the three phases which students' fluency improved in each phases due to less of halting and fragmentary conversation; (5) in comprehension, students tend to understand the flow of conversation and engaged in a dialogue, but requires occasional repetition and rephrasing. Moreover, this study found that the students have different personalities and it influences them to adapt the situation when they were as a guest star. For instance, nervous and speechless before conversation or blame to each other when broadcaster asked them to be the first speaker to give their opinion about the topic at that time, in contrast, there was no significant barrier between broadcaster and students interaction due 


\section{Volume 5, Number 02, December 2019}

to before airing they had short briefing to create warm and relax atmosphere. Additionally, when interaction between students and callers was happening, the barrier was student sometimes did not understand the questions coming from callers because callers asked them by phone line and the voice usually not clear enough and student found words that they did not understand and never heard before.

Other findings showed that few of students saw themselves as 'shy and speechless' and it means they are failed to communicate the topic with clear meaning. Following transcription conversation identified that they shy and speechless:

1. Eеeее.....ееее....

2. Ok....eеeе....eеeе... criteria of teacher .... eеeе.... who has ...eеeе

3. Maya...еееееее....

4. And...eeeeee....be...hbhmmmmm....yourself

5. Eeeeh.....for....twelve two...eeehhh...genesis people...hmmmmm...eeee...hmmmm

Anxiety also appeared as some of the students seemed afraid and nervous when they started to open the conversation due to they were afraid of using inappropriate vocabulary and language error. Following transcription conversation identified that that they are anxious.

1. Ahbhh... (her phone fall down)..eeee... my hobby is playing basketball

2. (Ira and Indah blame for each other to be the first speaker)

3. ( silent for a minute) eeeeee.....eeeeeee....experience, every sunday usually I go to beach with my family

4. Ok....eeeee....eeee...criteria of eeeeee....good teacher...eeee ( speechless and nervous, she did not continue speaking)

For the conversation above, this study found that the students afraid to start the conversation as well as they are getting confused and were silent for a minute. In order to create good conversation, students must prepare what they want to say.

\section{E. CONCLUSION AND IMPLICATIONS}

From the findings and discussion above, this study indicates that the implementation of media (radio talk show programme) assists students to improve their speaking skill as they are able to directly practice their speaking skill using media and this is in line with previous studies conducted by Sudharita (2005) and Harry (2010). It can be one of method in teaching and learning process especially in speaking class, because of using media could influence students' speaking skill in fluency and comprehension and also students will be more excited in learning English especially to improve their speaking skill. Moreover, this study found that the influence of media (radio talk show programme) could encourages and motivates students to pull out their best in practice of their speaking skill when they were asked as a guest star, this finding in 
Dewi Satria Elmiana, Improving Students' Speaking...

line with study proposed by Biagy (1996). Additionally, this study has some implications: (1) for the next researcher who wants to find out the solution of how to improve students' speaking skill especially by using media; (2) for teacher. To sum up, it could be benefited to use media or build partnership with radio or TV companies to provide a space for students to gain their confidence in speaking skill using target language.

\section{REFERENCES}

Bethesda, M.D. (2007). Information about hearing, communication and understanding. National Institutes of Health (US).

Bernard, H.R. (2002). Research Methods in Anthropology: Qualitative and quantitative methods. California: AltaMira Press

Biagi, S. (1996). Media Reader. Wadsworth. New York

Bygate, M (1987). Speaking. Oxford: Oxford University Press

Celce- Murcia, M. (2001). Teaching English as a second or foreign language (3rd Ed). Boston: Heinle $\&$ Heinle.

Efrizal, D.(2012). Improving students' speaking through communicative language teaching method at Mts Ja- alhaq, Sentot Ali Basa Islamic Boarding School of Bengkulu, Indonesia. International journal of humanities and social science, 2 (20), p. 127-134.

Elmiana, D.S. (2018). A critical analysis of tasks in senior high school EFL textbooks in Indonesia. The Journal of Asia TEFL, 15(2), p. 462-470.

Harry, W. (2010). Active listening in peer interviews: the influence of message paraphrasing on perceptions of listening skill. International Journal of Listening, 24 (1), p. 34 -49.

Heaton, J.B. (1991). Speaking English language testing. London: Longman.

Hubbard, P. (1995). Reality and authenticity: A critical look at modern ELT materials. MEXTESOL Journal, 18(2), 9-21.

Klapper, J. (2003). Taking communication to ask? A critical review of recent trend in language teaching. Communicative Language Teaching, 27(1), p. 33-42.

Lewis, J.L. \& S.R.J. Sheppard (2006). Culture and communication: can landscape visualization improve forest management consultation with indigenous communities. Landscape and Urban Planning, 77, p. 291-313.

Nunan, D. (2004). Task-based language teaching. Cambridge: Cambridge University Press.

Surakhmad, W. (1994). Pengantar Penelitian Ilmiah: Dasar Metode Teknik. Bandung: Tarsito

Surkamp, C. (2014). Non - verbal communication: why we need it in foreign language teaching and how we can foster it with drama activities. Scenario, 8 (2), p. 12-27.

Tafani, V. (2009). Teaching English through mass media. Acta Didactica Napocensia, 2 (1), p. 81 96. 